\title{
Morfoanatomia dos órgãos vegetativos de Smilax polyantha Griseb. (Smilacaceae) $^{1}$
}

\author{
ALINE REDONDO MARTINS² e BEATRIZ APPEZZATO-DA-GLÓRIA ${ }^{3,4}$
}

(recebido: 24 de março de 2005; aceito: 31 de agosto de 2006)

\begin{abstract}
Morphoanatomy of vegetative organs of Smilax polyantha Griseb. (Smilacaceae)). Smilax polyantha Griseb., known as salsaparrilha, is a medicinal plant, occurring in the "cerrado", in the Southeast region in Brazil. The objective of this study was to describe the morphoanatomy of the vegetative organs of Smilax polyantha and to verify whether the characters described in the Brazilian Pharmacopoeia allow to differentiate between salsaparrilha species. Samples of the vegetative organs were prepared following usual techniques using light and scanning electron microscopy. The leaf is hypostomatic and the stomata are paracytic. Mesophyll tends to dorsiventral, as the three parenchyma layers near the adaxial surface are constituted by sinuous cells. Petiole is canaliculated in the adaxial face, and striated in the abaxial face, indicating leaf twist. The stem branch was studied in the aerial and underground portion differing only by the thickening degree of vascular parenchyma cell walls. The rhizophore coat is made by cortical parenchyma; between the cortex and the vascular cylinder there is a secondary thickening meristem; the vascular cylinder has collateral bundles surrounded by parenchyma cells with thick secondary walls. The adventitious radicular system possesses white fresh roots, covered by epidermis, with large cortex, and rigid brown roots, covered by the sclerenchymatous cells of inner cortex, because the epidermis and outer cortex are eliminated along the development. The S. polyantha root analysis had shown that the parameters described in the Brazilian Pharmacopoeia, which are based on the way the roots are tied in bundles, the diameter, and colour of the roots, are insufficient to differentiate the Smilax species.
\end{abstract}

Key words - anatomy, leaf, root, salsaparrilha, underground stem

RESUMO - (Morfoanatomia dos órgãos vegetativos de Smilax polyantha Griseb. (Smilacaceae)). Smilax polyantha Griseb., conhecida como salsaparrilha, é uma espécie reconhecida como medicinal, encontrada em áreas de cerrado, especialmente na região Sudeste. O objetivo desse estudo foi descrever a morfoanatomia dos órgãos vegetativos de Smilax polyantha e verificar se os caracteres descritos na Farmacopéia Brasileira de fato permitem diferenciar esta das demais espécies denominadas salsaparrilha. Amostras dos órgãos vegetativos foram preparadas segundo técnicas usuais em microscopia de luz e eletrônica de varredura. A folha é hipoestomática e os estômatos são paracíticos. O mesofilo tende a dorsiventral, pois o parênquima adaxial é constituído por células com sinuosidades pronunciadas. O pecíolo é canaliculado, sulcado na porção abaxial, indicando torção foliar. O ramo caulinar foi estudado na porção aérea e subterrânea diferindo apenas pelo espessamento da parede das células do parênquima vascular. O rizóforo é revestido pelo córtex; entre o córtex e o cilindro vascular há o meristema de espessamento secundário; o cilindro vascular é constituído de feixes colaterais cercados por células parenquimáticas com espessamento parietal secundário. O sistema radicular adventício fibroso possui raízes brancas tenras, revestidas pela epiderme e raízes marrons rígidas revestidas pelo córtex interno esclerificado, já que a epiderme e córtex externo são eliminados ao longo do desenvolvimento. Visto que as espécies brasileiras de salsaparrilha indicadas como medicinais na Farmacopéia Brasileira são identificadas através do modo como as raízes são amarradas em feixes, do diâmetro da raiz e da sua coloração, as análises nas raízes de $S$. polyantha mostraram que esses parâmetros são insuficientes para diferenciar as espécies do gênero Smilax.

Palavras-chave - anatomia, caule subterrâneo, folha, raiz, salsaparrilha

\section{Introdução}

O gênero Smilax consta da Farmacopéia Brasileira de 1929 com as espécies Smilax papiracea Poiret,

1. Parte da dissertação de mestrado do primeiro autor, Programa de Pós-Graduação em Ciências Biológicas (Botânica) da Universidade Estadual Paulista, Instituto de Biociências, Botucatu, SP, Brasil.

2. Universidade Estadual Paulista, Instituto de Biociências, Departamento de Botânica, Caixa Postal 510, 18618-00 Botucatu, SP, Brasil.

3. Universidade de São Paulo, Escola Superior de Agricultura "Luiz de Queiroz", Departamento de Ciências Biológicas, Caixa Postal 9, 13418-900 Piracicaba, SP, Brasil.

4. Autor para correspondência: bagloria@esalq.usp.br
S. syphilitica Humboldt ex Bonpland, S. officinalis Kunth e $S$. medica Cham. ex Schlecht., denominadas como salsaparrilha, sendo descritas de acordo com o modo como as raízes são amarradas em feixes da seguinte maneira: "feixes cilíndricos formados de raízes cortadas em pedaços do mesmo comprimento, que atingem até $1,5 \mathrm{~m}$, colocadas paralelamente e amarradas por cipó; feixes cilíndricos, mais ou menos compactos, de comprimentos e diâmetros variáveis, formados de raízes cortadas e envolvidas por outras da mesma planta; ou ainda, feixes desatados ou comprimidos em pacotes, sendo que cada feixe contém de 20 a 30 raízes dobradas 
e fixadas a uma cepa com um ou mais rizomas grossos". Além da observação da maneira como os feixes de raízes são amarrados, a distinção entre as espécies também se baseia em características como comprimento e coloração externa das mesmas, bem como pela proporção entre os tecidos do córtex e cilindro vascular em secção transversal.

Em 1997, Andreata fez a revisão do gênero Smilax no Brasil. A autora descreveu 31 espécies como válidas, sendo 14 exclusivamente brasileiras. Das 31 espécies, 11 são denominadas salsaparrilhas, sendo que oito destas possuem propriedades medicinais, dentre elas Smilax polyantha Griseb.

Devido às características morfológicas e composição química semelhante entre as espécies do gênero Smilax e entre essas e o gênero Herreria a identificação taxonômica fica dificultada (Lorenzi 2002).

Cunha $(1937,1940)$ e Stellfeld (1940) comentam a falsificação da salsaparrilha, ou seja, a utilização de Herreria salsaparrilha Mart. com propósitos medicinais, atribuindo a essa espécie a mesma denominação e as propriedades medicinais de Smilax aspera L., utilizada na Europa.

A correta identificação e a caracterização morfoanatômica das plantas são fundamentais para o controle de qualidade da matéria-prima utilizada na elaboração de fitoterápicos, garantindo desta forma, a confiabilidade dos mesmos (Ming 1994). De acordo com Ferreira et al. (1998), a indústria farmacêutica nacional de fitoterápicos necessita investir na pesquisa, especialmente no controle de qualidade para atingir os padrões mundiais.

Dentre os trabalhos disponíveis na literatura a respeito da importância dos estudos morfoanatômicos para a separação das espécies de Smilax, destacam-se o de Vandercolme (1947) que analisou raízes de Smilax comercializadas em toda a América, na Europa Meridional, China e Japão. Cunha (1937) e Stellfeld (1940) verificaram que a estrutura interna da raiz é que realmente proporciona o maior número de elementos para diagnose segura da espécie não só pela característica dos tecidos como também pela proporção entre córtex, tecidos vasculares e medula. Caponetti \& Quimby (1956) estudaram a anatomia foliar, caulinar e radicular de cinco espécies: $S$. auriculata Walt., S. hispida Muhl., S. glauca Walt., S. bona-nox L., S. herbacea L. Ervin \& Evert (1967) estudaram o floema em $S$. rotundifolia L. Martin \& Tucker (1985) analisaram ápices caulinares em $S$. bona-nox L., S. rotundifolia L., S. laurifolia L. e S. pumila Walter. Oliveira et al. (1973) e Andreata \& Menezes (1999) estudaram o sistema subterrâneo de $S$. japecanga Griseb. e $S$. quinquenervea Vell., respectivamente.

Visto que os problemas de falsificação da salsaparrilha ainda ocorrem nos dias de hoje (Lorenzi 2002), que faltam estudos de caráter anatômico e ontogenético com mais espécies, para solucionar os problemas relacionados à morfologia do gênero Smilax (Andreata 1997) e que a correta identificação e a caracterização morfoanatômica das plantas são fundamentais para o controle de qualidade da matériaprima utilizada na elaboração de fitoterápicos (Ming 1994), o presente trabalho propõe descrever a morfoanatomia dos órgãos vegetativos de Smilax polyantha Griseb., espécie típica do Cerrado, empregada como planta medicinal (Andreata 1997) e verificar se os caracteres radiculares descritos para as quatro espécies de Smilax, citadas na Farmacopéia Brasileira, de fato permitem a diferenciação entre essas e a espécie Smilax polyantha.

\section{Material e métodos}

Material botânico - Espécimens de Smilax polyantha Griseb. foram coletados no período de julho de 2003 a dezembro de 2004, na propriedade particular "Fazenda Palmeira da Serra",

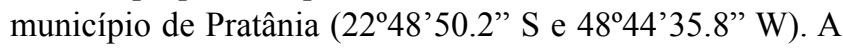
espécie foi identificada pela especialista Profa. Dra. Regina Helena Potsch Andreata e as exsicatas registradas e incorporadas ao acervo do Herbário da Escola Superior de Agricultura "Luiz de Queiroz" da Universidade de São Paulo, com os seguintes registros: ESA 88146, ESA 88145, ESA 88147.

Foram utilizados três indivíduos adultos, sendo analisada, na folha completamente expandida, a região mediana da lâmina foliar (na porção da nervura central, área internervural e bordo). O pecíolo (com as suas gavinhas) e a bainha foram analisados em toda a sua extensão em folhas jovens e em folhas completamente expandidas. O caule foi analisado na região do terceiro entrenó, na parte aérea próxima ao solo e na sua porção subterrânea. Também foram feitas análises do ápice caulinar. No sistema subterrâneo, além do rizóforo, segundo terminologia adotada por Andreata \& Menezes (1999), foram analisadas as raízes adventícias emitidas por ele em diferentes estágios de desenvolvimento.

As amostras acima descritas foram fixadas em FAA 50 (Johansen 1940). As secções (transversais e longitudinais) feitas à mão-livre (folhas, caules e raízes) e em micrótomo de deslize (caules e sistema subterrâneo) com 60-90 $\mu \mathrm{m}$ de espessura foram clarificadas com hipoclorito de sódio a $20 \%$, lavadas em água destilada. Alguns cortes foram corados com verde iodo e vermelho congo (Dop \& Gautié 1928) e montados em gelatina glicerinada. Outros cortes foram corados em safranina e azul de astra (Bukatsch 1972, Burger \& Richter 1991), desidratados em série etílica, acetato de butila $50 \% \mathrm{e}$ 
$100 \%$ e montados em resina sintética "Entellan".

Amostras dos órgãos vegetativos também foram desidratadas em série etílica, infiltradas com a resina plástica (Leica Historesin), os blocos obtidos foram seccionados a 8-10 $\mu \mathrm{m}$ de espessura. O material foi corado com azul de toluidina $0,05 \%$ em tampão fosfato e ácido cítrico $\mathrm{pH} 4,5$ (Sakai 1973) e em tampão fosfato e ácido acético pH 4,7 (O’Brien et al. 1964).

Amostras de folhas e do ramo caulinar subterrâneo foram fixadas em solução de FAA em etanol 50\% (Johansen 1940), desidratadas em série etílica até álcool absoluto. Em seguida, foram desidratadas pelo método do ponto crítico de $\mathrm{CO}_{2}$ (Horridge \& Tamm 1969) e montadas sobre suportes de alumínio e cobertas com uma camada de ouro de 30 a $40 \mathrm{~nm}$. As observações foram feitas ao microscópio eletrônico de varredura modelo LEO VP 435, operado a $20 \mathrm{kV}$.

Alguns testes foram realizados utilizando-se secções de material fixado em FAA em etanol 50\% (Johansen 1940). As secções foram feitas à mão-livre, com auxílio de lâmina de barbear e em micrótomo de deslize. A presença de substâncias lipídicas foi visualizada pelo emprego de Sudan IV e Sudan Black B (Jensen 1962). As lâminas foram montadas com o próprio reagente ou em água destilada. A presença de amido foi verificada pelo cloreto de zinco iodado (Strasburger 1913) e pelo reagente Lugol (Berlyn \& Miksche 1976); a presença de compostos fenólicos pelo emprego de cloreto férrico (Johansen 1940), a presença de lignina foi evidenciada por meio da floroglucina em meio ácido (Johansen 1940) e as substâncias pécticas evidenciadas pelo vermelho de rutênio (Johansen 1940).

As fotomicrografias foram feitas em fotomicroscópio, com as escalas micrométricas fotografadas e ampliadas nas mesmas condições ópticas utilizadas. Também foi utilizado microscópio trinocular Leica DM LB, acoplado na câmera de vídeo modelo Leica DC 300 F, sendo que as imagens foram capturadas no microcomputador.

A morfologia dos órgãos vegetativos foi documentada por meio de fotografias com máquina digital, além disso, foram feitas ilustrações do sistema subterrâneo.

\section{Resultados}

Smilax polyantha Griseb. possui folhas completas inseridas espiraladamente no ramo (figura 1). Há um par de gavinhas, de origem peciolar, no limite entre o pecíolo e a bainha (figura 2). $\mathrm{Na}$ axila das folhas, há uma ou duas gemas, cada qual envolvida completamente pelo profilo (figura 2).

O limbo foliar possui formato variável de ovado a ovado-lanceolado, consistência coriácea; o ápice agudo ou obtuso com pequeno mucro; base arredondada ou cordada; margem plana, espessa, de coloração esbranquiçada; venação em rede, com cinco nervuras principais curvinérveas, sendo a central mais evidente (figura 1).
O pecíolo de Smilax polyantha é pouco visível em primórdios foliares (figura 3). Em folhas muito jovens é possível diferenciar o pecíolo da bainha pelo fato de que a bainha é bilabiada. Nas folhas adultas (figura 2), o profilo dificulta a visualização da bainha, sendo o limite entre a bainha e o pecíolo, reconhecido pelo par de gavinhas (figura 2). Nessa fase, o pecíolo é canaliculado na face adaxial, mede aproximadamente meio centímetro de comprimento (figura 2) e possui sulcos na face abaxial (figura 4).

Na lâmina foliar, a epiderme em ambas as faces é unisseriada (figuras 5,6 ) e revestida por cutícula ornamentada (escamiforme) (figura 7).

Em vista frontal, as paredes das células epidérmicas da face adaxial são sinuosas (figura 8). Em alguns setores, ocorrem grupos de duas a três células de tamanho menor e com paredes retas. Em seção transversal estas células são também menores que as demais células epidérmicas (figura 5).

$\mathrm{Na}$ face abaxial, as células possuem paredes retas e os estômatos são paracíticos. A folha é hipoestomática (figura 9).

O mesofilo tende a dorsiventral, pois as três camadas voltadas para a face adaxial e que ocupam a metade do limbo, são constituídas de células de tamanho maior com sinuosidades pronunciadas (figuras 5,10 ) e arranjo quase justaposto. As demais camadas do mesofilo são constituídas por células com formato arredondado ou células braciformes típicas de parênquima lacunoso (figura 5).

Entre as células do parênquima clorofiliano ocorrem idioblastos contendo ráfides e mucilagem e também esclereídes, que podem ser de três tipos (figura 11): esclereídes colunares, esclereídes fibriformes e osteoesclereídes. Tais esclereídes também podem estar associadas aos feixes vasculares. Na região do bordo, o mesofilo é constituído por células lignificadas (dados não ilustrados).

Os feixes vasculares laterais são do tipo colateral. Os feixes maiores são completamente envolvidos por células lignificadas que podem atingir ambas as faces da epiderme. Nos feixes menores há apenas uma calota de células lignificadas voltada para o xilema e outra para o floema (figura 6 ).

A nervura central, em corte transversal na região mediana, apresenta epiderme unisseriada e cutícula espessa. Na face abaxial, as duas camadas de células subepidérmicas apresentam células de paredes espessadas e algumas células de conteúdo fenólico. Sob essas camadas há o colênquima anelar (dados não ilustrados). Há aproximadamente cinco feixes 
vasculares maiores e cinco feixes vasculares menores distribuídos em forma de arco, envolvidos pelo periciclo esclerificado (figura 12).

No pecíolo adulto (figuras 13-16) a epiderme é unisseriada revestida com cutícula espessa (figuras 14 , 16). O córtex (figura 14) possui hipoderme unisseriada cujas células acumulam compostos fenólicos, e oito camadas de colênquima anelar. Ainda no córtex, podem ser encontrados idioblastos com ráfides e fibras isoladas. O cilindro vascular é constituído por aproximadamente quinze feixes, sendo cada feixe envolvido individualmente pelo periciclo esclerificado (figura 13). A medula também apresenta células colenquimatosas.

$\mathrm{Na}$ região dos sulcos ocorrem ondulações na epiderme, o espessamento parietal do colênquima é maior e não ocorre a lignificação das células que envolvem os feixes vasculares (figuras 15,16 ).

Através de cortes seriados (figuras 17-21), desde o limite do pecíolo com o limbo foliar (figura 17) até o ponto de inserção da bainha no ramo (figura 21), observa-se que a origem das gavinhas é peciolar, pois à medida que se aproxima a saída das gavinhas, ocorre lignificação da hipoderme, o número de camadas do colênquima angular diminui e o número de feixes vasculares aumenta, sendo que a bainha de fibras não individualiza mais cada feixe, mas sim une todo o cilindro vascular. Na região próxima à saída das gavinhas, é possível visualizar três cilindros vasculares (figuras 18 , 19), os quais tornam-se independentes do pecíolo (figura 20).

A estrutura anatômica das gavinhas e da bainha foliar é semelhante a do pecíolo. A bainha foliar ao aproximar-se do caule torna-se gradualmente laminar, apresentando meristema intercalar assim como ocorre no pecíolo (figura 21).

A bainha foliar juntamente com o profilo envolve completamente a gema axilar da folha (figuras 21,22).

No terceiro entrenó do ramo caulinar aéreo (figuras 23, 26), a epiderme apresenta-se unisseriada com cutícula fina, o córtex é formado por aproximadamente seis camadas de células parenquimáticas e o cilindro vascular é amplo com os feixes ainda em diferenciação distribuídos aleatoriamente.

$\mathrm{Na}$ região do ramo caulinar próxima ao solo (figuras 24,27), a epiderme é recoberta por uma cutícula espessa. No córtex, observa-se a hipoderme unisseriada com algumas células de paredes espessas e lignificadas e o colênquima anelar (figura 24). O cilindro vascular pode ser dividido em duas regiões: região periférica (próxima ao córtex) onde os feixes vasculares são menores e mais próximos e as células parenquimáticas ao redor dos mesmos possuem paredes espessas e lignificadas; região central onde feixes vasculares são maiores e ocorre pouco espessamento das paredes das células parenquimáticas ao redor dos mesmos (figura 24).

$\mathrm{Na}$ região subterrânea do ramo caulinar (figuras 25,28 ), observa-se epiderme unisseriada, recoberta por cutícula espessa, onde também podem ser encontrados estômatos (figura 29). Em seguida, observa-se hipoderme unisseriada constituída de células com paredes levemente espessas e lignificadas (figura 24). O restante do córtex possui entre seis e 12 camadas de células parenquimáticas com amplos espaços intercelulares. No cilindro vascular ocorre espessamento parietal secundário em todas as células parenquimáticas que circundam os feixes vasculares (figura 28). Em todas as regiões analisadas do ramo caulinar, o feixe vascular é colateral com amplos elementos de metafloema providos de placa crivada composta (figura 30) e de elementos de metaxilema providos de placa de perfuração escalariforme (figura 31).

Em um dos exemplares coletados, são verificados nós intumescidos no ramo caulinar subterrâneo (figura 32). A estrutura é bastante complexa, pois além do ramo caulinar subterrâneo de coloração mais escura, há desenvolvimento da gema axilar formando outro ramo caulinar. A base desse outro ramo é espessada e a partir dela formam-se raízes adventícias. As análises anatômicas seriadas da região nodal intumescida (figuras 33-38) mostram que o espessamento na base do ramo caulinar em desenvolvimento resulta da instalação de uma faixa meristemática (figuras 35-38) de origem pericíclica (figura 38). Essa faixa origina feixes vasculares completos (figura 37) centripetamente, primórdios radiculares e gemas caulinares (figura 33). Tal faixa corresponde ao que se convencionou chamar na literatura de meristema de espessamento primário (PTM). A localização da endoderme e do periciclo na região intumescida foi possível pelo acompanhamento da saída de uma raiz adventícia, pois nessa espécie o córtex interno da raiz é lignificado (figura 38).

A análise seriada também permitiu observar a distribuição dos tecidos vasculares, a formação dos primórdios de raízes e gemas adventícias (figura 33). Tais gemas são protegidas por catafilos. Os catafilos apresentam epiderme unisseriada e aproximadamente doze camadas de células parenquimáticas entre as quais ocorrem idioblastos ora contendo ráfides ora contendo fenóis (figura 34).

O rizóforo de $S$. polyantha possui coloração externa marrom e textura rígida, mede 

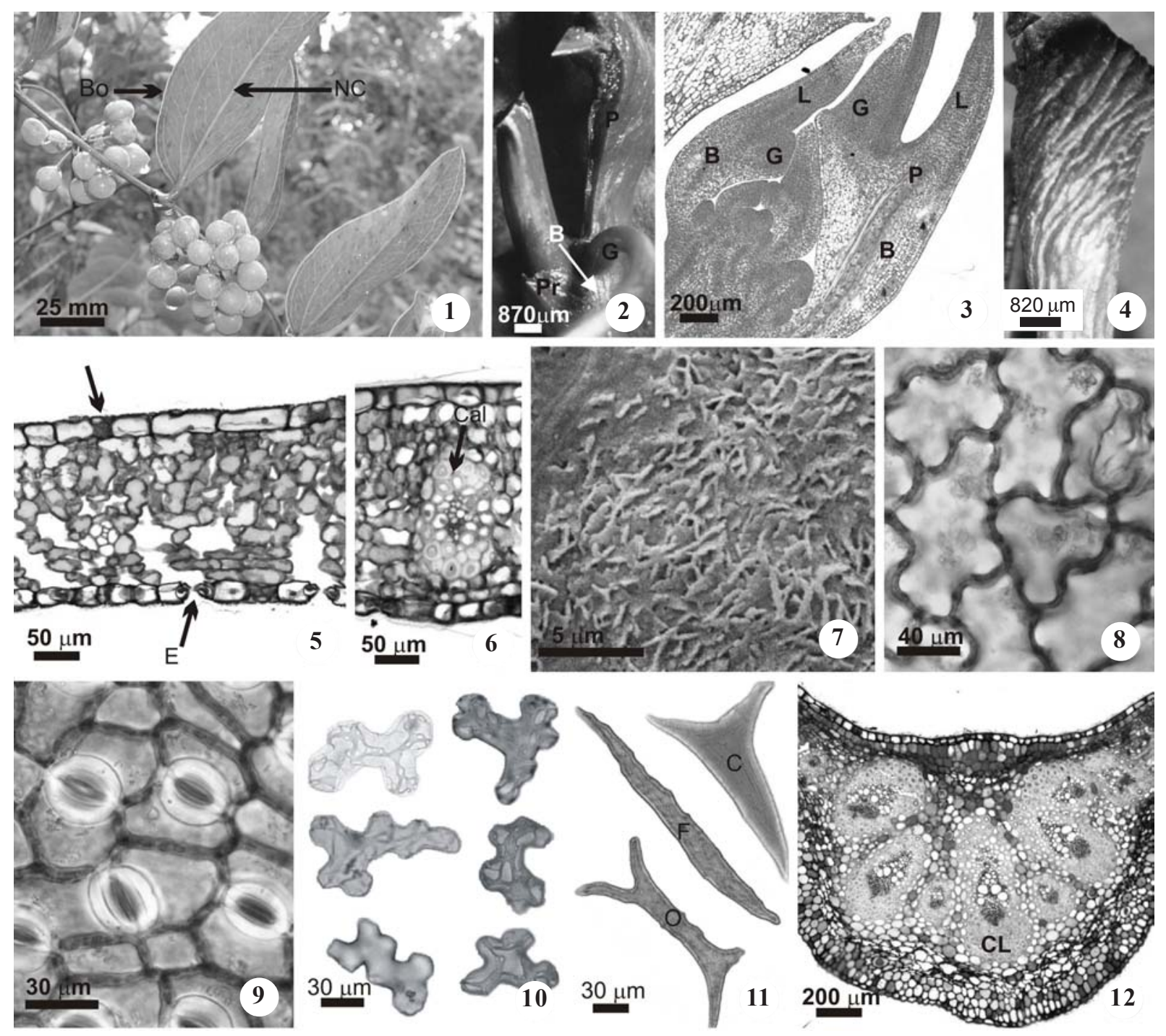

Figuras 1-12. 1. Visão geral de Smilax polyantha Griseb. no cerrado. 2. Folha adulta com o limbo removido. O pecíolo é canaliculado; as duas gavinhas estabelecem o limite entre o pecíolo e a bainha. 3. Secção longitudinal do ápice caulinar, mostrando primórdios foliares. 4. Detalhe dos sulcos na região abaxial do pecíolo. 5-6. Secções transversais do limbo foliar. 5. Observar na face adaxial células epidérmicas de tamanho menor (seta) e na face abaxial, os estômatos com grandes cavidades subestomáticas. 6. Feixe vascular do tipo colateral com uma calota de células lignificadas voltada para o xilema e outra voltada para o floema. 7. Eletromicrografia de varredura da cutícula escamiforme da face adaxial. 8. Vista frontal da epiderme da face adaxial com células de paredes sinuosas. 9. Vista frontal da epiderme abaxial com estômatos do tipo paracítico. 10-11. Tipos de células presentes no limbo foliar obtidas a partir de tratamento para dissociação celular: células sinuosas do parênquima paliçádico (10) e esclereídes (11). 12. Secção transversal da nervura central de uma folha adulta. $(\mathrm{B}=$ bainha; $\mathrm{Bo}=$ bordo foliar; $\mathrm{C}=$ esclereide colunar; $\mathrm{Cal}=$ calota de células lignificadas; $\mathrm{CL}=$ células lignificadas; $\mathrm{E}=$ estômato; $\mathrm{F}=$ esclereide fibriforme; $\mathrm{G}=$ gavinha; $\mathrm{L}=$ limbo; $\mathrm{NC}=$ nervura central $; \mathrm{O}=$ osteoesclereíde; $\mathrm{P}=$ pecíolo; $\mathrm{Pr}=$ profilo).

Figures 1-12. 1. General view of Smilax polyantha Griseb. in the cerrado. 2. Mature leaf after removing the lamina. Petiole is canaliculated; the two tendrils establish the limit between petiole and sheath. 3. Longitudinal section of the shoot apex with leaf primordia. 4. Detail of the striated abaxial face of the petiole. 5-6. Transversal sections of the leaf lamina. 5. Note in the adaxial surface epidermis cells with smaller size (arrow) and in the abaxial surface, stomata with large substomatal chamber. 6. Collateral vascular bundle with cap of fibers outerside the xylem and phloem. 7. Scale-like cuticle on the adaxial surface. 8 . Frontal view of the adaxial surface showing sinuous cells. 9. Frontal view of the paracytic stomata of the abaxial surface. 10-11. Types of cells found in the foliar lamina obtained through cellular dissociation treatment: sinuous palisade parenchyma cells (10) and sclereids (11). 12. Transversal section of the midrib of a mature leaf. $(\mathrm{B}=$ sheath; $\mathrm{Bo}=$ foliar edge; $\mathrm{C}=$ columnar sclereid; $\mathrm{Cal}=$ cap of lignified cells; $\mathrm{CL}=$ lignified cells; $\mathrm{E}=$ stoma; $\mathrm{F}=$ filiform sclereid; $\mathrm{G}=$ tendril; $\mathrm{L}=$ lamina; $\mathrm{NC}=$ midrib; $\mathrm{O}=$ osteosclereid; $\mathrm{P}=$ petiole; $\mathrm{Pr}=$ prophyll). 


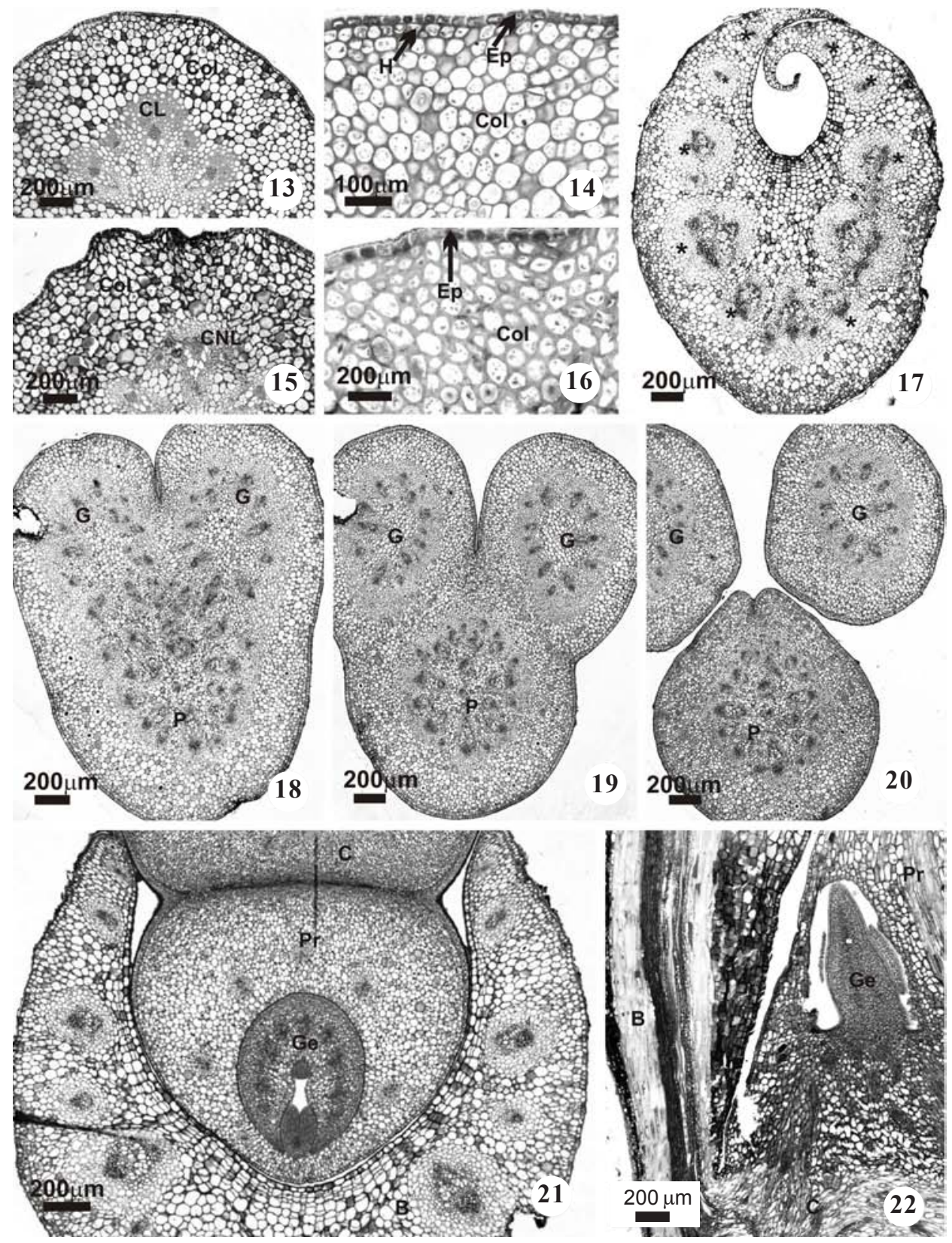

Figuras 13-22. Secções transversais do pecíolo de Smilax polyantha Griseb. 13-14. Região do pecíolo próximo ao limbo foliar. 13. Feixes envolvidos por células lignificadas. 14. Colênquima anelar. 15-16. Visão do pecíolo na região de torção com epiderme ondulada (15) e espessamento do colênquima (16). 17-21. Secções transversais do pecíolo jovem. 17. Região do pecíolo próximo ao limbo (* = feixes vasculares individualizados). 18. Região do pecíolo próximo à saída da gavinha. 19. Os cilindros vasculares das gavinhas e do pecíolo já estão individualizados. 20. Gavinhas separadas do pecíolo. 21. Bainha e profilo envolvendo a gema axilar. 22. Inserção da bainha no caule. $(B=$ bainha; $C=$ caule; $C L=$ células parenquimáticas lignificadas; $\mathrm{CNL}=$ células parenquimáticas não lignificadas; $\mathrm{Col}=$ colênquima; $\mathrm{Ep}=$ epiderme; $\mathrm{G}=$ gavinha; $\mathrm{Ge}=\mathrm{Gema}$ axilar; $\mathrm{H}=$ hipoderme; $\mathrm{P}=$ pecíolo; $\mathrm{Pr}=$ profilo) .

Figures 13-22. Transversal sections of Smilax polyantha Griseb. petiole. 13-14. Region of petiole near to the leaf lamina. 13. Bundles surrounded by lignified cells. 14. Collenchyma. 15-16. Striated region of the petiole with undulated epidermis (15) and thickened collenchyma (16). 17-21. Transversal sections in an immature petiole. 17. Petiole region near to the lamina (* = distinct vascular bundles). 18. Petiole region near to the tendrils emission. 19. The vascular cylinder of each tendril and petiole are distinct. 20. Tendrils are separated of the petiole. 21. Axillary bud surrounded by the sheath and prophyll. 22. Insertion of the sheath in stem. $(\mathrm{B}=$ sheath; $\mathrm{C}=$ stem; $\mathrm{CL}=$ lignified parenchyma cells; $\mathrm{CNL}=$ not lignified parenchyma cells; $\mathrm{Col}=$ collenchyma; $\mathrm{Ep}=$ epidermis; $\mathrm{G}=$ tendril; $\mathrm{GE}=$ axillary bud; $\mathrm{H}=$ hypodermis; $\mathrm{P}=$ petiole; $\mathrm{Pr}=$ prophyll). 


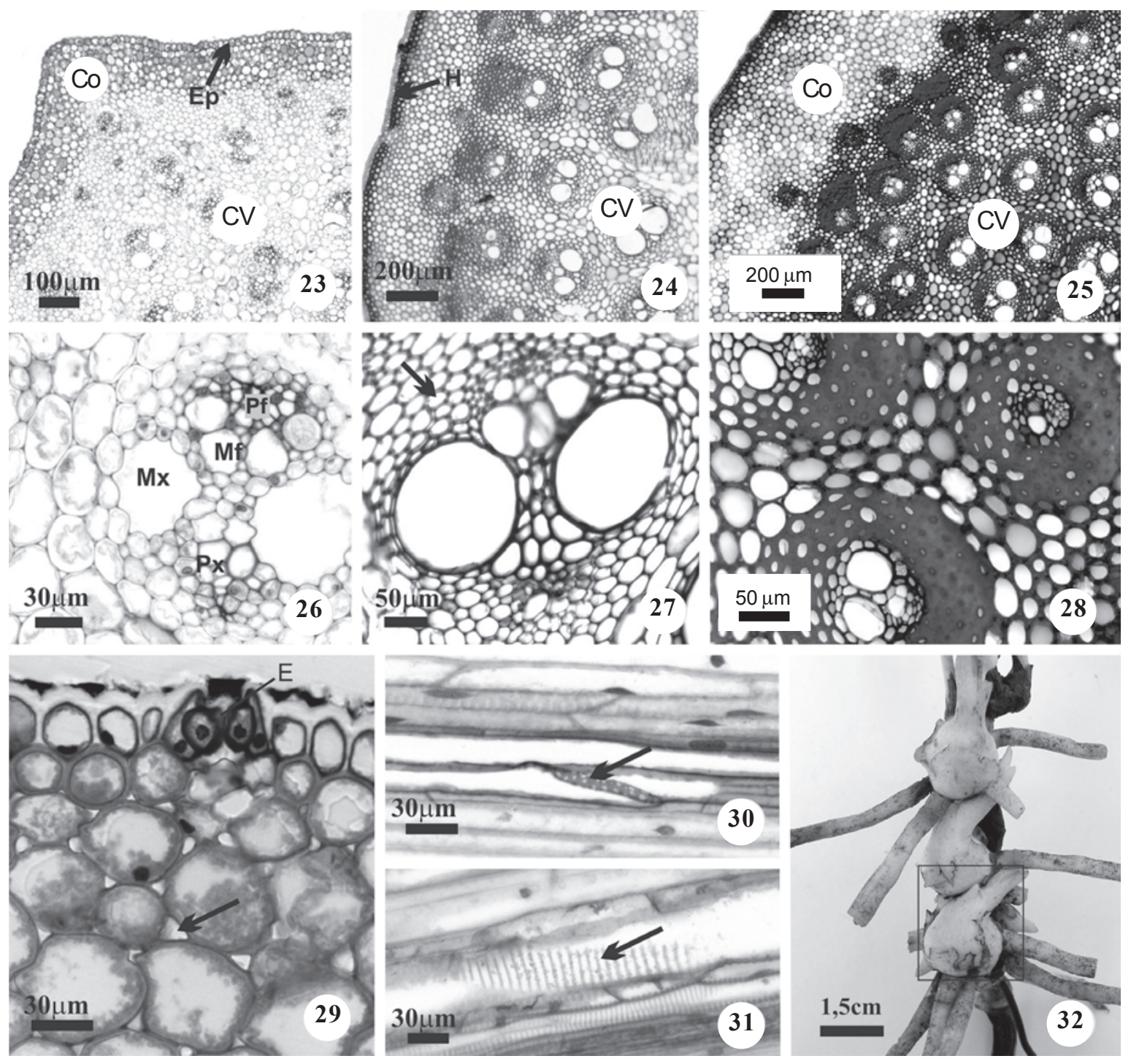

Figuras 23-32. Ramo caulinar de Smilax polyantha Griseb. 23-29. Secções transversais do ramo caulinar aéreo. 23, 26. Caule aéreo na região do terceiro entrenó. 24, 27. Ramo caulinar aéreo na porção próxima ao solo. 25, 28. Secção transversal do ramo caulinar subterrâneo. 23-25. Visão geral. 26. Feixe vascular em diferenciação. 27. Feixe vascular da área central do cilindro cercado por células sem lignificação (seta). 28. Feixes vasculares cercados de células parênquimáticas com paredes espessas e lignificadas. 29. Detalhe do estômato e dos espaços intercelulares no córtex (seta). 30-31. Secções longitudinais do ramo caulinar subterrâneo mostrando placa crivada composta (seta) e placa de perfuração escalariforme (seta), respectivamente. 32. Visão geral do ramo caulinar com espessamento na região nodal (detalhe). $(\mathrm{Co}=$ córtex; $\mathrm{CV}=$ cilindro vascular; $\mathrm{E}=$ estômato; $\mathrm{Ep}=$ epiderme; $\mathrm{H}=$ hipoderme; $\mathrm{Mf}=$ metafloema; $\mathrm{Mx}=$ metaxilema; $\mathrm{Pf}=$ protofloema; $\mathrm{Px}=$ protoxilema).

Figures 23-32. Stem branch of Smilax polyantha Griseb. 23-29. Transversal sections of the aerial stem branch. 23, 26. Aerial stem in the third internode. 24, 27. Aerial stem branch near to the ground. 25, 28. Transversal section of the underground stem branch. 23-25. General view. 26. Vascular bundles in differentiation. 27. Vascular bundles of the central area of the cylinder surrounded by cells not lignified (arrow). 28. Vascular bundles surrounded by parenchyma cells with thick and lignified walls. 29. Detail of the stoma and the intercellular spaces in the cortex (arrow). 30-31. Longitudinal sections of the underground stem branch showing the composed sieve plate (arrow) and scalariform perforation plate (arrow). 32. General view of the stem branch with dilated node region (detail). $(\mathrm{Co}=$ cortex; $\mathrm{CV}=$ vascular cylinder; $\mathrm{E}=$ stoma; $\mathrm{Ep}=$ epidermis; $\mathrm{H}=$ hypodermis; $\mathrm{Mf}=$ secondary phloem; $\mathrm{MX}=$ secondary xylem; $\mathrm{Pf}=$ primary phloem; $\mathrm{Px}=$ primary $\mathrm{xylem})$. 
aproximadamente 10 centímetros de comprimento, apresenta orientação horizontal, e é constituído de porções globulares interligadas (figura 39), denominados artículos segundo Andreata (1997). A partir dos artículos mais periféricos, observa-se a formação de ramos caulinares e raízes adventícias de coloração branca e diâmetro maior. A partir dos artículos centrais podem ser observadas raízes adventícias de coloração marrom e diâmetro menor (figura 39).

Em secção transversal do rizóforo, observa-se sua coloração avermelhada natural (figura 40), e, em maiores aumentos, verifica-se que ocorre a perda das
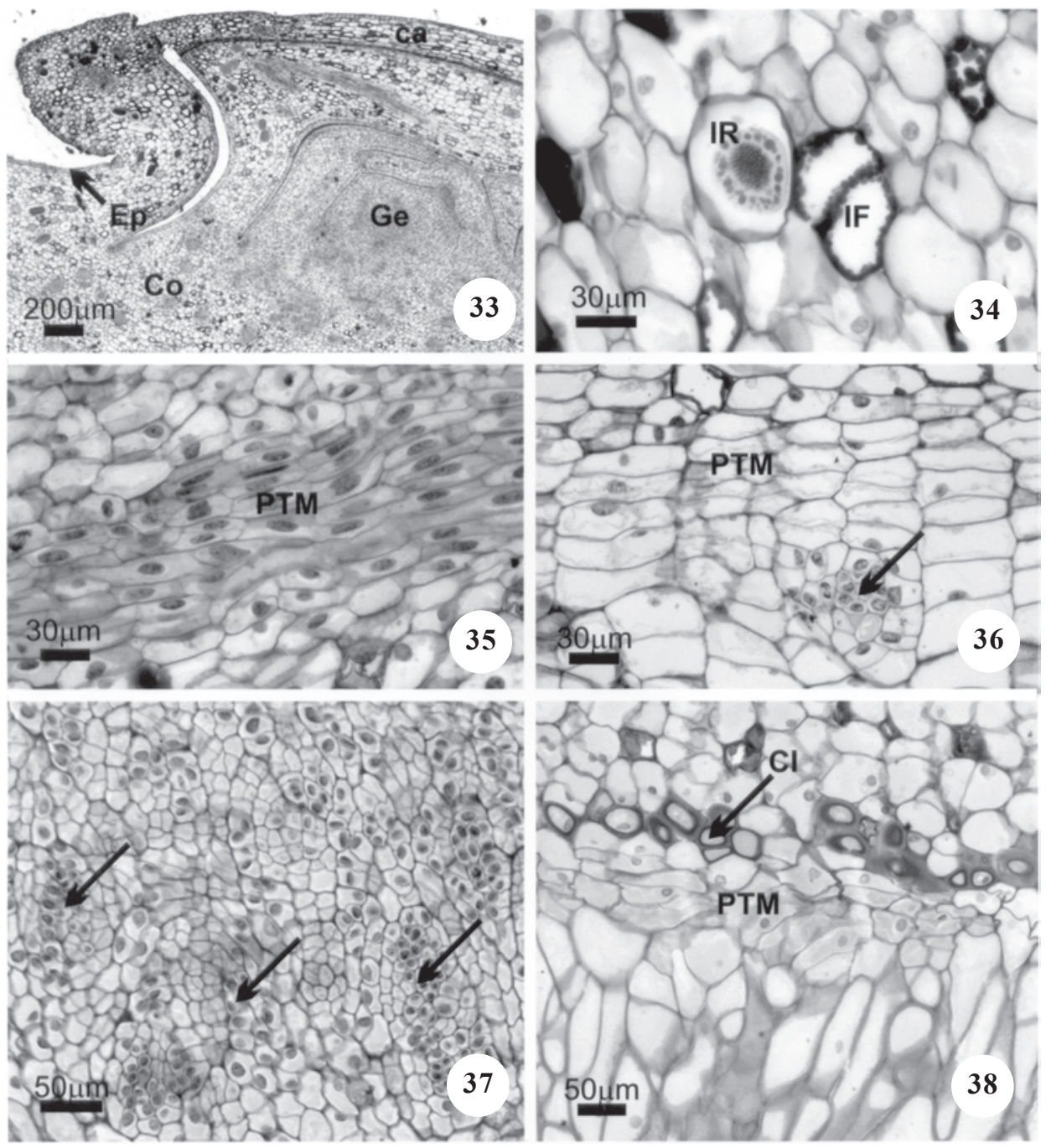

Figuras 33-38. Secções transversais da porção do ramo caulinar de Smilax polyantha Griseb. com espessamento da região nodal. 33. Gema caulinar adventícia recoberta por catafilos. 34. Idioblastos com ráfides e com compostos fenólicos. 35. Meristema de espessamento primário. 36. PTM com detalhe de feixe vascular (seta) em diferenciação. 37. Feixes vasculares originados pelo PTM (setas). 38. Córtex interno de uma raiz adventícia constituído por duas camadas de células lignificadas (seta). ( $\mathrm{ca}=$ catafilo; $\mathrm{Co}=$ córtex $\mathrm{CI}=$ córtex interno; $\mathrm{Ep}=$ epiderme; $\mathrm{Ge}=$ gema caulinar adventícia; $\mathrm{IF}$ = idioblasto contendo compostos fenólicos; IR = idioblasto contendo ráfides; PTM = meristema de espessamento primário).

Figures 33-38. Transversal sections of the portion of the stem branch of Smilax polyantha Griseb. with dilated node region. 33. Adventitious shoot bud recovered by cataphylls. 34. Idioblasts with raphides and phenolic compounds. 35. Primary thickening meristem. 36. PTM with vascular bundles in differentiation (arrow). 37. Vascular bundles originated by the PTM (arrows). 38. Inner cortex of an adventitious root consisting by two layers of lignified cells (arrow). (ca = cataphyll; $\mathrm{Co}=\mathrm{cortex}$; $\mathrm{CI}=$ inner cortex; $\mathrm{Ep}=$ epidermis; $\mathrm{Ge}=$ stem adventitious bud; IF = idioblast with phenolic compounds; IR = idioblast with raphides; PTM = primary thickening meristem). 
células epidérmicas, sendo que o novo revestimento é realizado pelo córtex (figura 41) que possui entre 10 a vinte camadas de células parenquimáticas e idioblastos com conteúdo fenólico ou idioblastos com ráfides. Entre o córtex e o cilindro vascular, observa-se uma faixa meristemática que é quase contínua (figura 41), ou seja, o meristema de espessamento secundário. O meristema de espessamento secundário (STM) forma células que originam novos feixes vasculares (figura 42) e células corticais. Como em um típico espessamento secundário, também são formados raios parenquimáticos entre os novos feixes vasculares (figura 42). A faixa meristemática formada pelas células do meristema de espessamento secundário é contínua com a endoderme e periciclo das raízes adventícias originadas a partir do rizóforo, e também parece ser mais ativa próxima às gemas caulinares adventícias.

O cilindro vascular do rizóforo é constituído por feixes vasculares do tipo colateral (figura 43), os quais são envolvidos por células que acumulam amido e possuem paredes espessadas e lignificadas (figura 43). Idioblastos contendo substâncias fenólicas podem ser encontrados entre as células parenquimáticas do cilindro vascular do rizóforo.

O sistema radicular adventício fibroso de Smilax polyantha pode originar-se da região nodal e do entrenó do órgão subterrâneo (figura 39), ou da porção nodal subterrânea dos ramos caulinares onde ocorre intumescimento (figura 32). Esse sistema é constituído de raízes longas distribuídas principalmente na direção horizontal em relação ao solo, podendo alcançar mais de um metro de comprimento. São verificadas raízes tenras, de coloração branca a quase translúcida e raízes rígidas de coloração marrom e diâmetro menor.

$\mathrm{O}$ ápice radicular (figura 44) possui organização do tipo aberta, é envolvido pela coifa cuja columela apresenta estatolitos e não forma estratificação típica. $\mathrm{Na}$ zona de diferenciação é possível verificar a formação de idioblastos contendo ráfides no córtex e na medula.

Ao seccionar a raiz branca na região próxima ao ápice radicular, observa-se a estrutura anatômica em diferenciação. Nessa, o revestimento é feito pela epiderme. O córtex é amplo e constituído de exoderme, parênquima cortical e endoderme (figuras 45, 46).

O parênquima cortical divide o córtex em dois setores: externo e interno, devido às características das células. No córtex externo há várias camadas de células isodiamétricas arranjadas deixando amplos espaços intercelulares (figura 45). Já o córtex interno é formado por duas camadas de células alongadas justapostas e providas de paredes primárias não espessadas (figura 46). A endoderme possui estrias de Caspary pouco evidentes mesmo quando corada com Sudan IV.

O cilindro vascular é poliarco e sifonostélico (figura 45). O periciclo é bisseriado e constituído de células com paredes primárias delgadas. A medula é ampla e parenquimática.

Numa fase posterior do desenvolvimento, é possível observar que a exoderme é unisseriada e suas células são altas e justapostas. Além disso, suas paredes radiais e algumas periclinais externas possuem substâncias lipídicas (dados não ilustrados).

Com o desenvolvimento, ocorre progressivamente o espessamento secundário da parede das células do córtex interno (figura 47) que apresenta substâncias lipídicas e lignina.

Também ocorre espessamento da endoderme, que passa a apresentar reforço em "O", do periciclo e do parênquima vascular (figuras 47-50).

À medida que a raiz se desenvolve, o córtex externo vai sendo progressivamente eliminado (figura 48) de tal forma que nas raízes de coloração marrom o córtex externo está ausente e o córtex interno, provido de células de paredes espessadas altamente lignificadas, passa a exercer a função de revestimento (figura 49). Tais raízes armazenam amido no parênquima medular (figura 50).

Em algumas raízes mais velhas, o parênquima medular pode degenerar na porção central da medula.

\section{Discussão}

Yates \& Duncan (1970), ao estudarem a anatomia foliar de Smilax auriculata Walt., S. bona-nox L., S. glauca Walt., S. laurifolia L., S. rotundifolia L., S. smallii Morong, S. tamnoides L. e S. walteri Pursh, descrevem as células da epiderme na face abaxial de S. glauca como papilosas, fato que também ocorre em grupos de células de menor tamanho na epiderme de $S$. polyantha Grisebach, porém na epiderme da superfície adaxial. Os mesmos autores também descrevem o mesofilo como dorsiventral. Em Smilax polyantha preferimos adotar mesofilo tendendo a dorsiventral, pois na folha adulta as células do parênquima paliçádico são lobadas assemelhando-se àquelas do parênquima lacunoso e diferindo do parênquima paliçádico típico cujas células são alongadas e dispostas em fileiras. $\mathrm{O}$ parênquima paliçádico lobado pode ser encontrado em Bambusa sp. e Pinus sp. (Menezes et al. 2003), porém não há registro na literatura desse parênquima em outras espécies de Smilax. 
Marquete \& Pontes (1994) descrevem a cutícula de $S$. spicata Vell. e $S$. rufescens Griseb. como lisa e a de S. fluminensis Steudel como ondulada. Em S. polyantha, a cutícula é escamiforme seguindo a descrição de Metcalfe \& Chalk (1979).

De acordo com Andreata (1997), a presença de sulcos na face abaxial do pecíolo indica a torção dos mesmos, o que determina a posição da lâmina foliar. De fato, em $S$. polyantha verifica-se nessa região a ausência de lignificação das células ao redor dos feixes vasculares e espessamento parietal por substâncias pécticas mais pronunciado, que são indicativos da movimentação peciolar (Machado \& Rodrigues 2004).

Caponetti \& Quimby (1956) e Ervin \& Evert (1967), sugerem que o ramo caulinar aéreo das espécies de Smilax por eles estudadas possui a porção mais externa do cilindro vascular na forma de um anel esclerificado e, na porção interna, os feixes possuem uma bainha
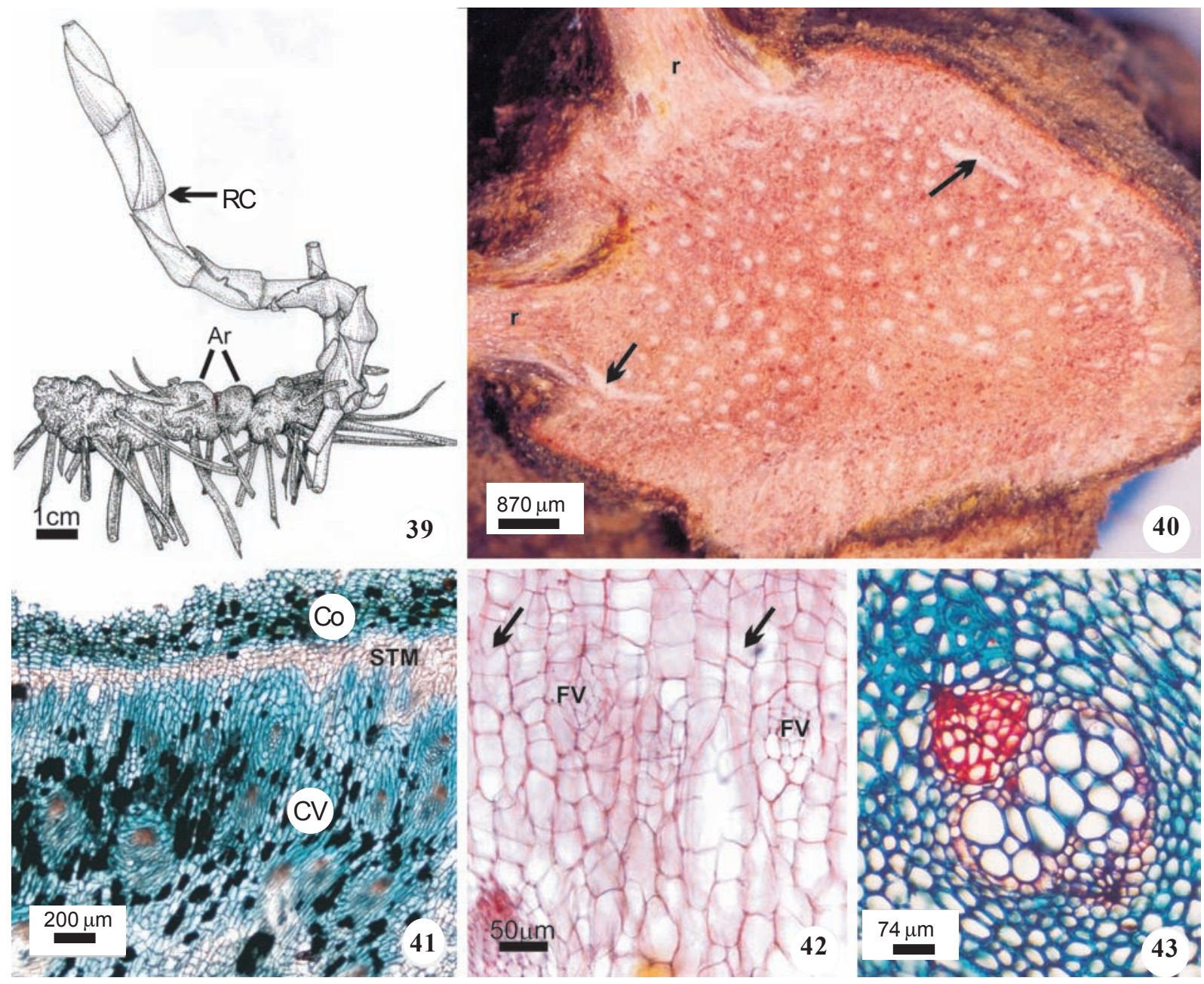

Figuras 39-43. Rizóforo de Smilax polyantha Griseb. 39. Aspecto geral. 40. Corte transversal do rizóforo com saída de raízes adventícias e o meristema de espessamento secundário indicado pelas setas. 41. Secção transversal do rizóforo. 42. Detalhe do parênquima em arranjo radial (setas) e feixes vasculares originados pelo STM. 43. Detalhe do feixe vascular colateral cercado por células parenquimáticas de paredes espessas. $(\mathrm{Ar}=$ artículo; $\mathrm{Co}=$ córtex; $\mathrm{CV}=$ cilindro vascular; $\mathrm{FV}=$ feixe vascular; $\mathrm{r}=$ raiz adventícia; $\mathrm{RC}=$ ramo caulinar; $\mathrm{STM}=$ meristema de espessamento secundário).

Figures 39-43. Rhizophore de Smilax polyantha Griseb. 39. General view. 40. Transversal section of rhizophore with adventitious roots and secondary thickening meristem (arrows). 41. Transversal section of rhizophore. 42. Detail of radial arrangement of parenchyma (arrows) and vascular bundles originated by the STM. 43. Detail of the collateral vascular bundle surrounded by parenchyma cells with thick walls. $(\mathrm{Ar}=$ chain of tubers; $\mathrm{Co}=$ cortex; $\mathrm{CV}=$ vascular cylinder; $\mathrm{FV}=$ vascular bundle; $\mathrm{r}=$ adventitious root; $\mathrm{RC}=$ stem branch; $\mathrm{STM}=$ secondary thickening meristem). 


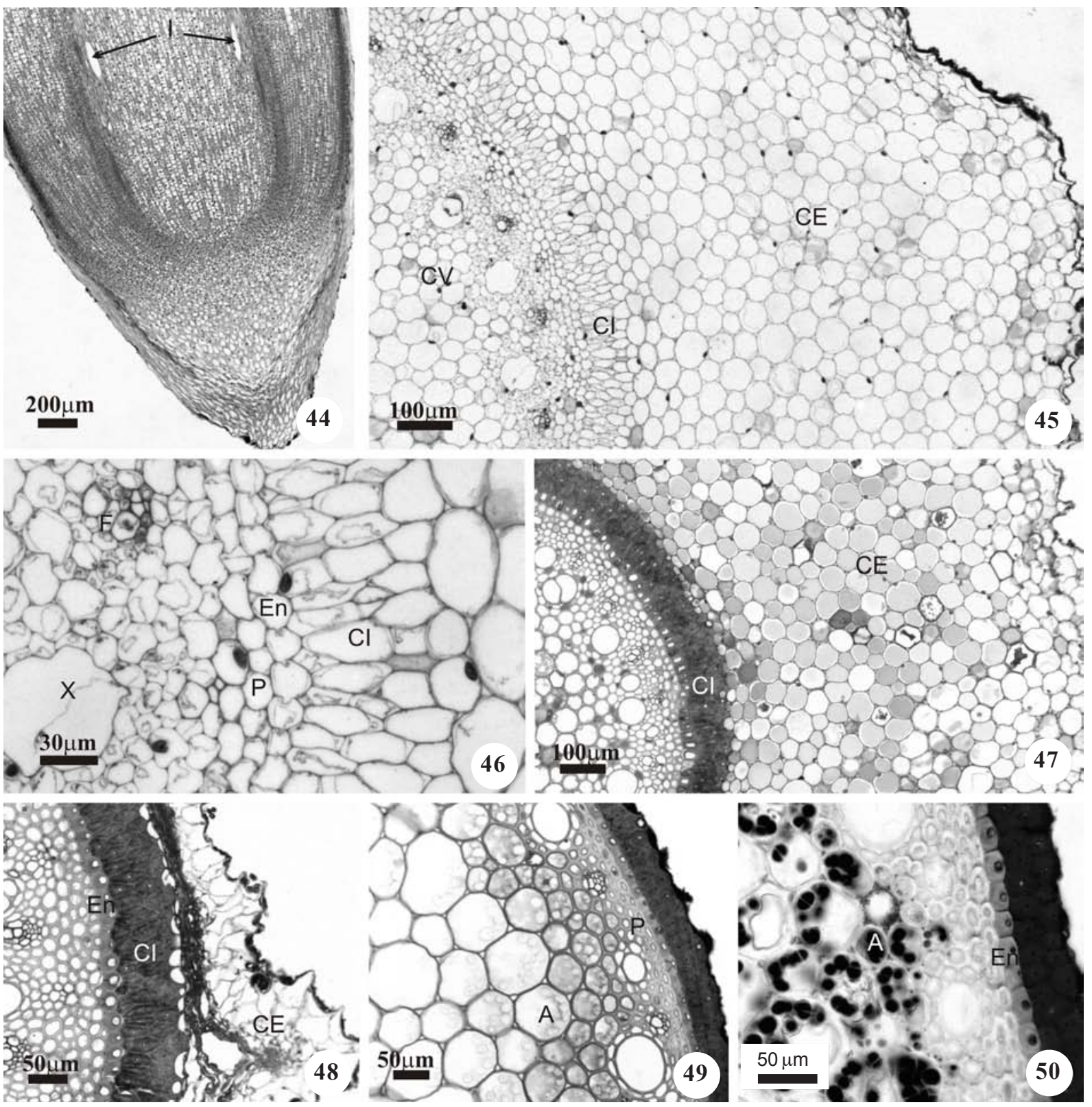

Figuras 44-50. Raiz de Smilax polyantha Griseb. 44. Secção longitudinal do ápice radicular. 45-46. Secções transversais da raiz branca em diferenciação. 47. Início de espessamento secundário das paredes do córtex interno na raiz branca. 48 . Resquícios do córtex externo na raiz marrom. 49. Raiz marrom cujo novo revestimento é o córtex interno. 50. Grãos de amido nas células parenquimáticas da medula. $(\mathrm{A}=$ amido; $\mathrm{CE}=$ córtex externo; $\mathrm{CI}=$ córtex interno; $\mathrm{CV}=$ cilindro vascular; En $=$ endoderme; $\mathrm{F}=$ floema; $\mathrm{I}=$ idioblasto; $\mathrm{P}=$ periciclo; $\mathrm{X}=$ xilema $)$.

Figures 44-50. Roots of Smilax polyantha Griseb. 44. Longitudinal section of the root apex. 45-46. Transversal section of the white root in differentiation. 47. Secondary walls thickening of the inner cortex cells in the white root. 48 . Vestige of the outer cortex in the brown root. 49. Brown root whose new covering is the inner cortex. 50. Starch grains in the pith parenchyma cells. $(\mathrm{A}=$ starch; $\mathrm{CE}=$ outer cortex; $\mathrm{CI}=$ inner cortex; $\mathrm{CV}=$ vascular cylinder; $\mathrm{En}=$ endodermis; $\mathrm{F}=$ phloem; $\mathrm{I}=\mathrm{idioblast}$; $\mathrm{P}=$ pericycle; $\mathrm{X}=$ xylem). 
individual de esclerênquima. Em $S$. polyantha o grau de lignificação das células varia de acordo com a região do ramo caulinar analisada e está associado ao estágio de diferenciação do órgão, portanto esse caráter não pode ser utilizado como indicativo de diagnose.

De acordo com Ervin \& Evert (1967), os elementos de tubo crivado do metafloema de $S$. rotundifolia $\mathrm{L}$. podem apresentar placas crivadas simples e transversais como também placas crivadas compostas e oblíquas. Em nosso trabalho, observamos placas crivadas compostas e oblíquas. Sendo assim, essas características podem variar entre as espécies, podendo ser usadas como fatores microscópicos para ajudar a diferenciar espécies.

Segundo DeMason (1980) e Rudall (1991), o meristema de espessamento primário é o responsável pelo espessamento do caule em monocotiledôneas, além da produção de raízes adventícias e formação de conexões entre a vascularização do caule, da raiz e das folhas. Em S. polyantha, na porção nodal intumescida do ramo caulinar subterrâneo observa-se a presença de um meristema o qual forma centripetamente feixes vasculares completos e, em alguns setores, raízes adventícias. Analisando topograficamente pode-se dizer que o meristema de espessamento primário é o próprio periciclo em atividade meristemática concordando com as observações de Menezes et al. (2005) para outras monocotiledôneas.

Em relação ao caule subterrâneo, muitos autores tais como Davis (1891), Holm (1890), Caponetti \& Quimby (1956), Oliveira et al. (1973) descrevem o sistema subterrâneo do gênero Smilax como rizoma, e ainda podemos encontrar na literatura a denominação de xilopódio (Almeida et al. 1998). A partir dos trabalhos de Andreata (1997) e Andreata \& Menezes (1999), a estrutura subterrânea do gênero Smilax foi reinterpretada, adotando-se o termo rizóforo, devido a formação de dois sistemas de gemas: um que forma o sistema vegetativo aéreo (origem a partir da plúmula do embrião) e outro, um sistema vegetativo subterrâneo, denominado rizóforo (origem a partir da gema cotiledonar). Visto que $S$. polyantha apresenta dois sistemas caulinares e que todo o sistema radicular adventício é formado pelo sistema caulinar subterrâneo, optamos por adotar esse termo no presente estudo.

Nas espécies estudadas por Caponetti \& Quimby (1956), os autores descrevem a presença da periderme como tecido de revestimento do sistema subterrâneo. Em $S$. polyantha não foi verificada periderme. $\mathrm{O}$ revestimento do rizóforo é constituído pelo córtex. Segundo Zimmermann \& Brown (1977), em muitas espécies de palmeiras, o parênquima da superfície do caule localizado subterraneamente torna-se suberizado para formar o revestimento protetor externo e a parte mais externa do córtex pode sofrer desgaste e ser eliminada nos caules mais velhos.

Segundo DeMason (1983), o STM é análogo ao câmbio vascular das dicotiledôneas, já que produz tecidos de maneira bidirecional, ou seja, contribui tanto para o formação de novas células do córtex como também novas células do tecido vascular. Esta produção de células de maneira bidirecional também foi observada no rizóforo de $S$. polyantha no qual o meristema de espessamento secundário produz centrifugamente $\mathrm{o}$ córtex secundário e centripetamente os feixes vasculares e parênquima.

Na Farmacopéia Brasileira de 1929, as espécies de salsaparrilha indicadas como medicinais são identificadas através da maneira como as raízes são amarradas em feixes, do diâmetro da raiz e da sua coloração. No presente trabalho, pode-se concluir que esses dados são insuficientes para diferenciar as espécies do gênero Smilax, já que a espécie Smilax polyantha possui raízes as quais, dependendo do estágio de desenvolvimento, apresentam coloração de branca a marrom e diâmetros variados devido à perda do córtex externo. Cunha (1940) também já relata a perda do parênquima cortical em algumas espécies brasileiras do gênero. Portanto, os caracteres utilizados pela nossa Farmacopéia são variáveis dentro de uma mesma espécie. Se os parâmetros de qualidade para fins farmacêuticos são, em princípio, estabelecidos nas Farmacopéias e Códigos Oficiais e no caso das matérias-primas vegetais oriundas de plantas clássicas, ou seja, aquelas estudadas tanto do ponto de vista químico quanto farmacológico, existem monografias definindo critérios de identidade, pureza e teor de constituintes químicos (Farias 2001), mais estudos morfoanatômicos no gênero Smilax são necessários visando critérios melhores de identificação das espécies.

Agradecimentos - À Profa. Dra. Regina Helena Potsch Andreata, pela identificação dos espécimes vegetais. Às agências de fomento Capes (Coordenação de Aperfeiçoamento de Pessoal de Nível Superior) e CNPq (Conselho Nacional de Desenvolvimento Científico e Tecnológico), pela concessão de bolsas de estudo. À Fundação de Amparo à Pesquisa do Estado de São Paulo, pela concessão do auxílio financeiro para a execução desse estudo. Projeto Temático - Programa Biota, no 00/12469-3. Ao Prof. Dr. Elliot Watanabe Kitajima, do NAP/MEPA - EsalqUSP - Piracicaba-SP, pelo uso dos equipamentos para Microscopia Eletrônica de Varredura. 


\section{Referências bibliográficas}

ALMEIDA, S.P., PROENÇA, C.E.B., SANO, S.M. \& RIBEIRO, J.F. 1998. Cerrado: espécies vegetais úteis. Embrapa CPAC, Planaltina.

ANDREATA, R.H.P. 1997. Revisão das espécies brasileiras do gênero Smilax Linnaeus (Smilacaceae). Pesquisas-Botânica 47:7-244.

ANDREATA, R.H.P. \& MENEZES, N.L. 1999. Morfoanatomia do embrião, desenvolvimento pós-seminal e origem do rizóforo de Smilax quinquenervia Vell. Boletim de Botânica da Universidade de São Paulo 18:39-51.

BERLYN, G.P. \& MIKSCHE, J.P. 1976. Botanical microtechnique and cytochemistry. Iowa State University Press, Ames.

BUKATSCH, F. 1972. Bermerkungen zur Doppelfarbung Astrablau-Safranin. Mikrokosmos 61:255.

BURGER, L.M. \& RICHTER, H.G. 1991. Anatomia da Madeira. Nobel, São Paulo.

CAPONETTI, J.D. \& QUIMBY, M.W. 1956. The comparative anatomy of certain species of Smilax. Journal of the American Pharmaceutical Association 45:691-696.

CUNHA, N.S. 1937. Da salsaparrilha a japecanga. Tribuna Farmacêutica 5:145-150.

CUNHA, N.S. 1940. As salsaparrilhas em face da Farmacopéia Brasileira. Tribuna Farmacêutica 8:105-112.

DAVIS, W.T. 1891. Variations in rootstock of Smilax glauca dependent upon environment. Bulletin of the Torrey Botanical Club 18:118-119.

DEMASON, D.A. 1980. Localization of cell division activity in the primary thickening meristem in Allium cepa L. American Journal of Botany 67:393-399.

DEMASON, D.A. 1983. The primary thickening meristem: definition and function in monocotyledons. American Journal of Botany 70:955-962.

DOP, P. \& GAUTIÉ, A. 1928. Manuel de technique botanique. Lamarre, Paris.

ERVIN, E.L. \& EVERT, R.F. 1967. Aspects of sieve element ontogeny and structure in Smilax rotundifolia. Botanical Gazette 128:138-144.

FARIAS, M.R. 2001. Avaliação da qualidade de matérias primas vegetais. In Farmacognosia: da planta ao medicamento (C.M.O. Simões, E.P. Schenkel, G. Gosmann, J.C.P. Mello, L.A. Mentz \& P.R Petrovick, eds.). Ed. Universidade/UFRGS/UFSC, Porto Alegre/Florianópolis, p.199-222.

FARMACOPÉIA (PHARMACOPÉIA) DOS ESTADOS UNIDOS DO BRASIL. 1929. Redigida por SILVA, R.A.D. Companhia Editora Nacional, Rio de Janeiro.

FERREIRA, S.H., BARATA, L.E.S., SALLES, S.L.M., QUEIRÓZ, S.R.R., HELUY NETO, N.E., CORAZZA, R. \& FARIAS, R.C. 1998. Medicamentos a partir de plantas medicinais no Brasil. Academia Brasileira de Ciências, Rio de Janeiro.

HOLM, T. 1890. Contribution to the knowledge of the germination of some North American plants. Memoirs of the Torrey Botanical Club 2:57-108.
HORRIDGE, G.A. \& TAMM, S.L. 1969. Critical point drying for scanning electron microscopy study of ciliary motion. Science 163:817-818.

JOHANSEN, D.A. 1940. Plant microtechnique. McGraw-Hill, New York.

JENSEN, W.A. 1962. Botanical histochemistry: principle and practice. W.H. Freeman, San Francisco.

LORENZI, H. 2002. Plantas medicinais no Brasil: nativas e exóticas cultivadas. Instituto Plantarum, Nova Odessa.

MACHADO, S. R. \& RODRIGUES, T.M. 2004. Anatomia e ultra-estrutura do pulvino primário de Pterodon pubescens Benth. (Fabaceae - Faboideae). Revista Brasileira de Botânica 27:135-147.

MARQUETE, O. \& PONTES, R.G. 1994. Estudo anatômico foliar comparativo de Smilax spicata Vell., Smilax rufescens Griseb. e Smilax fluminensis Steudel. Revista Brasileira de Biologia 54:413-426.

MARTIN, B.F. \& TUCKER, S.C. 1985. Developmental studies in Smilax (Liliaceae) I. Organography and the shoot apex. American Journal of Botany 72:66-74.

MENEZES, N.L., SILVA, D.C. \& MELO-DE-PINNA, GF.A. 2003. Folha. In Anatomia Vegetal (B. Appezzato-da-Glória \& S.M. Carmello-Guerreiro, eds.). UFV, Viçosa, p. 303-325.

MENEZES, N.L., SILVA, D.C., ARRUDA, R.C.O., MELO-DEPINNA, G.F.A., CARDOSO, V.A., CASTRO, N.M., SCATENA, V.L. \& SCREMIN-DIAS, E. 2005. Meristematic activity of the endodermis and the pericycle in the primary thickening in monocotyledons. Considerations on the "PTM". Anais da Academia Brasileira de Ciências 77:259-274.

METCALFE, C.R. \& CHALK, L. 1979. Anatomy of the dicotyledons. Oxford University Press, New York.

MING, L.C. 1994. Estudos e pesquisas de plantas medicinais na agronomia. Horticultura Brasileira 12:3-9.

O’BRIEN, T.P., FEDER, N. \& McCULLY, M.E. 1964. Polychromatic staining of plant cell walls by toluidine blue O. Protoplasma 59:368-376.

OLIVEIRA, F., SILVA, J.B. \& ROCHA, A.B. 1973. Contribuição para o reconhecimento do rizoma de Smilax japecanga Grisebach. Revista da Faculdade de Farmácia e Odontologia de Araraquara 7:7-18.

RUDALL, P. 1991. Lateral meristems and stem thickening growth in monocotyledons. The Botanical Review 57:150-163.

SAKAI, W.S. 1973. Simple method for differential staining of paraffin embedded plant material using toluidine blue. Stain Technology 48:247-248.

STELLFELD, C. 1940. Sarçaparrilha e jupicanga. Tribuna Farmacêutica 8:193-202.

STRASBURGER, E. 1913. Handbook of practical botany. (Transl. W. Hillhouse). George Allen \& Company Ltda., London.

VANDERCOLME, E. 1947. História botânica e terapêutica das salsaparrilhas. Revista da Flora Medicinal 7-11:316-524.

YATES, I.E. \& DUNCAN, W.H. 1970. Comparative studies of Smilax, section Smilax, of the southeastern United States. Rhodora 72:289-312.

ZIMMERMANN, M.H. \& BROWN, C.L. 1977. Trees, structure and function. Springer-Verlag, New York. 